\title{
Brazilian plant specimens at the Regnellian herbarium: history and repatriation
}

\author{
Karin dos Santos ${ }^{1,2}$
}

\begin{abstract}
This article visits the history of Brazil-Sweden's partnership in botany and the contribution of Anders Fredrik Regnell and other botanical collectors to the knowledge of Brazilian flora. The importance of the herbarium of Stockholm (S) is widely recognized for its collections of Brazilian plants, one of the largest in the world. The majority of the collections from Brazil date from the period between the second half of nineteenth century and the beginning of the twentieth century. The main collectors of Brazilian flora from that phase, whose bulk of collections are in Stockholm are Anders Regnell, Gustaf Malme, Per Dusén, Carl Lindman and many others sponsored by the Regnellian fund. The herbarium also houses substantial collections of August Glaziou, a great contributor to the knowledge of the flora of state of Goiás, and Adolf Ducke, pioneer in the taxonomy of Amazonian tree species. The cooperation between Brazil and Sweden is currently being renewed through Rio de Janeiro Botanical Garden and the Reflora Program, allowing repatriation of Brazilian specimens housed in Stockholm.
\end{abstract}

Key words: reflora, digitization, repatriation, botanical history, Anders Regnell.

\begin{abstract}
Resumo
Este artigo aborda o histórico da parceria Brasil-Suécia em botânica e a contribuição de Anders Fredrik Regnell e outros coletores botânicos para o conhecimento da flora brasileira com coleções significativas na Suécia. A importância do herbário de Estocolmo (S) é amplamente reconhecida por suas coleções de plantas brasileiras, uma das maiores do mundo. A maioria das coleções do Brasil data do período compreendido entre a segunda metade do século XIX e início do século XX. Dentre os principais coletores da flora brasileira dessa fase, cuja maior parte de coleções estão em Estocolmo estão os suecos Anders Regnell, Gustaf Malme, Per Dusen, Carl Lindman e muitos outros. O herbário também abriga coleções substanciais de August Glaziou, grande contribuidor para o conhecimento da flora do estado de Goiás, e Adolf Ducke, pioneiro na taxonomia de espécies de árvores amazônicas. A cooperação entre Brasil e Suécia está sendo renovada através da parceria entre o Museu de História Natural de Estocolmo e o Jardim Botânico do Rio de Janeiro através do Programa Reflora, que permitirá o repatriamento de espécimes brasileiros alojados em Estocolmo.

Palavras-chave: reflora, digitalização, repatriamento, história botânica, Anders Regnell.
\end{abstract}

\section{Introduction}

The Regnellian herbarium and the Reflora Program

The development and dissemination of plant information resources have been one of the core businesses of botanical gardens and natural history collections for many decades (Lughadha \& Miller 2009). However, for historical reasons, many important South American plant specimens and the associated data are not easily accessible to researchers in the countries from which they were taken. To correct this distortion and facilitate access to these data and specimens, the Swedish Museum of Natural History and Rio de Janeiro Botanical Garden have begun a cooperation agreement in order to digitize and repatriate Brazilian specimens stored in European herbaria via the Reflora Program.

Initiated by the Brazilian National Research Council (CNPq), the Reflora Program consists of

\footnotetext{
Swedish Museum of Natural History, Department of Botany, P.O. Box 50007, SE-10405, Stockholm, Sweden.

${ }^{2}$ Author for correspondence: karin.santos@nrm.se
} 
a large-scale research and data-sharing project, which encompasses data capture, infrastructure enhancement, and capacity building in different herbaria partners from Brazil, Europe and North America.

The herbarium of Stockholm, joined the Reflora Program in 2015, and is among the ten largest herbaria in the world with about three million specimens of plants and fungi. The collections have immense historical and scientific value and have been used as the basis for research from all around the world. Among them, the most important historical collections include those of Carl von Linné (4,500 specimens), Olof Swartz (7,500 specimens), Olov Celsius (uncle of Anders Celsius, proponent of the Celsius scale) with 175 plants, and the personal herbarium of Anders F. Regnell. Regnell's collection was the foundation of the herbarium section currently bearing his name in the Swedish Museum of Natural History (S): the Regnellian herbarium, where more than 400,000 plant specimens collected in South and Central American are housed.

The estimated number of Brazilian samples in the Regnellian herbarium is 115,000 , collected mostly during the nineteenth century $(51 \%)$ and early twentieth century (30\%) (Fig. 1). The partnership aims to digitize and return to Brazil, images and information of these Brazilian specimens. The collection of types in the Regnellian herbarium includes around 25,000 specimens with almost 7,500 being from Brazil. Type collections are already digitized and available at Stockholm's virtual herbarium, Kripto-S, and at Reflora Virtual Herbarium.

The best represented families at the Brazilian collection are Asteraceae, with almost 11,500 specimens, representing $10 \%$ of stored material, Fabaceae with ca. 10,000 (9.3\%), Orchidaceae $4,500(4.2 \%)$, Apocynaceae 4,400 (4.1\%),

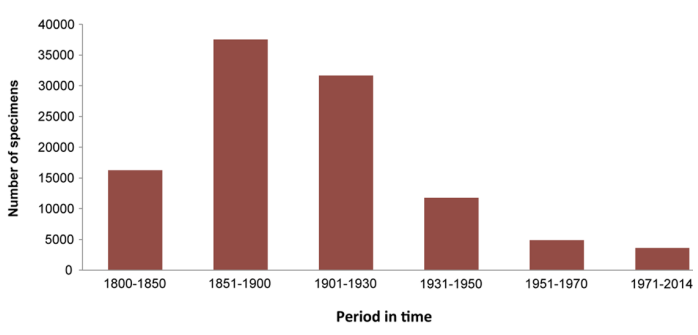

Figure 1 - Estimated number of plant specimens collected in Brazil per period stored in the Regnellian herbarium (S).
Table 1 - Great collectors whose main type collections are housed in the Regnellian herbarium (S) and the estimated number of regular (non-type) specimens.

\begin{tabular}{lcc}
\hline Colectors & $\begin{array}{c}\text { Type } \\
\text { specimens }\end{array}$ & $\begin{array}{c}\text { Regular } \\
\text { specimens* }\end{array}$ \\
\hline Anders F. Regnell & 1022 & 15546 \\
Per K. Dusén & 881 & 13401 \\
Gustav A. Malme & 778 & 11834 \\
Adolf Ducke & 653 & 9933 \\
Auguste F. Glaziou & 542 & 8245 \\
Boris A. Krukoff & 390 & 5932 \\
Hjalmar Mosén & 374 & 5689 \\
Carl A. Lindman & 337 & 5126 \\
Johan Widgren & 225 & 3423 \\
George Gardner & 210 & 3194 \\
Others & 2105 & 32020 \\
Total & 7517 & 114343 \\
\hline
\end{tabular}

* estimated numbers

Melastomataceae 4,100 (3.7\%), and Annonaceae, Myrtaceae and Poaceae with about 3,800 plants each (Fig. 2). Among the main collectors, we can mention Anders F. Regnell, Gustav A. Malme, Per K. Dusen, Adolf Ducke, Auguste F. Glaziou, Hjalmar Mosén, Carl M. Lindman, among many others (Tab. 1).

A great part of the Brazillian collections in the Regnellian herbarium were gathered during more than 20 Swedish expeditions to Brazil, starting

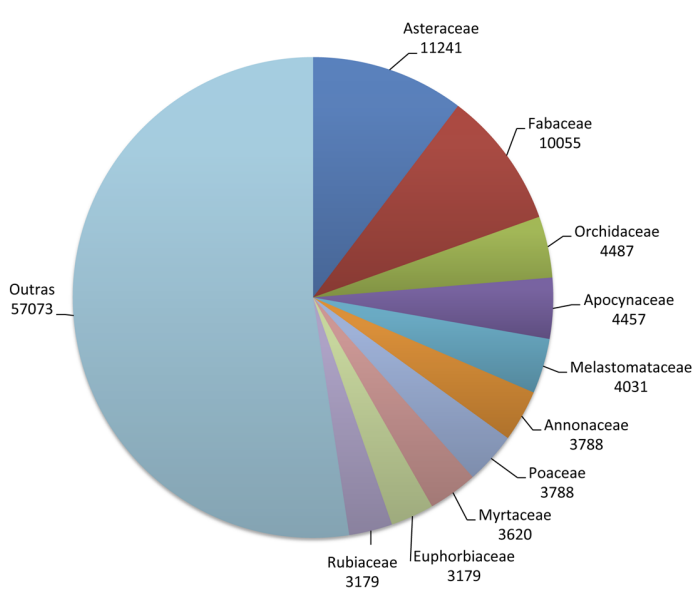

Figure 2 - Estimated number of plant specimens collected in Brazil according to families of phanerogams stored in the Regnellian herbarium (S). 
when Anders F. Regnell established himself in the country in the early nineteenth century. Plus, the active interaction among institutions and the work of curators and supporters throughout time assured the maintenance and continued growth of the Regnellian herbarium collections making it a world reference in Brazilian plants. Thanks to this renewed partnership, samples of enormous historical and scientific value will be digitized and made available to a Brazilian provider, thus facilitating access and query by researchers from all around the world.

\section{Great collectors of the Regnellian herbarium and its history in Brazil}

Anders Fredrik Regnell - the founder and mentor of Regnellian herbarium in Stockholm.

The physician and botanist Anders Fredrik Regnell (Fig. 3a) was born in Stockholm, in 1807, son of the unmarried housemaid Brita Persdotter and the coachman Anders Ringnell. He was left in an orphanage until 1809 , when his father married to a wealthy widow and took the boy to live with them. Although economically prosperous, his father and stepmother were very busy and no family life was offered to young Regnell. Despite that, at the age of seventeen, he was accepted at the medical school of Uppsala (Dahlgren 1962). One of his main interests already back then was botany, influenced by his professor, Göran Wahlenberg.

Soon after graduation in 1837, Regnell left Sweden for Brazil, mainly because of his lung fragility. Upon arriving in Brazil, he validated his medical degree at the Faculty of Medicine of Rio de Janeiro, which enabled him to practice medicine in his new country. He decided to settle in the small city of Caldas, Minas Gerais, due to its mild climate and medicinal waters, and he lived there until his death in 1884 (Lindberg 2011; Concha Quezada 2012).

Thanks to his solid background in medicine, Regnell had great success within that profession and became well known in the region. He started collecting plants while traveling on horseback to visit patients, and initiated his own herbarium, built in a room adjacent to his house (Fig. 3b-e). Over the years he acquired properties and coffee plantations and, in addition to the functions of a physician, administrator of lands, and botanist, he also became known as the money-lender of the district. Lending money at an interest rate of up to $20 \%$, helped him to increase his fortune considerably (Dahlgren 1962). It was however, his systematic collection of plants, his field trips, and the study of botany that gave him pleasure of living. His main motivation in this matter was to discover Brazilian flora and diversity and disclose it to Europe (Concha Quezada 2012).

Regnell maintained regular contact with his former university colleagues, science academies and researchers from various European countries, to whom he sent his collections periodically together with large sums of money to support Swedish botanical expeditions to Brazil (Lindman 1916). His most active correspondence was with his childhood friend Isaac G. Clason, the Stockholm based Professors Göran Wahlenberg and Nils Johan Andersson, and botanists Elias and Thore Fries from Uppsala. Most of his plant collections were sent to Stockholm, Uppsala, and Lund but he also dispatched collections to Carl Fiedrich $\mathrm{Ph}$. von Martius in Munich, George Bentham in London, Alphonse de Candolle in Genebra, Joseph Decaisne in Paris, Heinrich Gustav Reinchenbach in Hamburg, and Eugen Warming in Copenhagen (Concha Quezada 2012). He also maintained active contact with botanists in Brazil such as French Auguste F.M. Glaziou and Brazilian João Barbosa Rodrigues.

Thanks to Regnell's fortune and generosity, his house in Caldas became a safe haven for many botanists researching in Brazil, some of them fully supported by him. The first Swedish botanist to spend some time under Regnell's shelter was Johan F. Widgren, who worked and collected in different occasions with Regnell, during the period from 1841 to 1847 , reaching the impressive mark of 50,000 specimens collected (Concha Quezada 2012). Other important Swedish botanists who spent time there, and currently have their botanical collections in the Regnellian herbarium are Salomon E. Henschen (collected in 1867-69), Carl H. Mosén (collected in 1873), Gustaf A. Lindberg, and Albert Löfgren (Dahlgren 1962; Lindberg 2011).

Anders Regnell remained a bachelor and recluse. Because of his fragile health, he had very spartan habits. He didn't drink coffee, nor alcohol, didn't smoke, nor appreciate social occasions and, despite the wealth, used to dress simply and furnish the house modestly. All these factors combined with his Nordic appearance and dedication to science, conferred to "Doctor André", as he was known by the people of Caldas, a certain mystical air, but whose presence was a source of pride for the small town (Dahlgren 1962). 
His aspiration to create a "Brazilian Institution" in Sweden, in order to receive and store Brazilian collections, and sponsor Brazillian flora research was granted by The Royal Swedish Academy of Sciences in 1870, which established the headquarters of the institution conceived by Regnell, creating the Regnellian herbarium as a Brazilian division in the
Department of Botany at the Swedish Museum of Natural History (Lindman 1916). The Regnellian Fund, administrated by the Royal Swedish Academy of Sciences, was also created during that period to support research in the neotropics with resources originating from the fortune donated by Regnell and continuing until the present day.
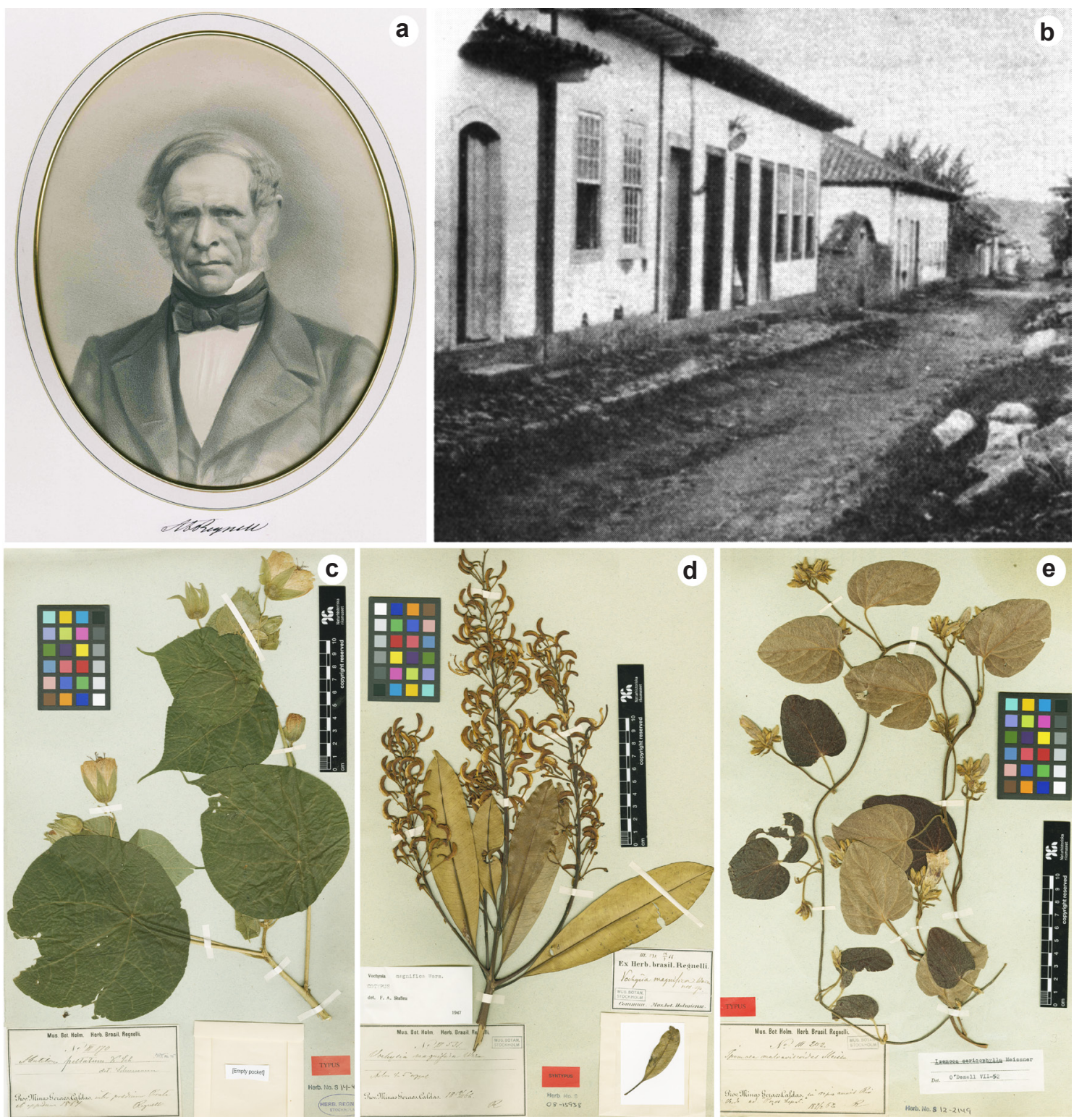

Figure 3 - Portrait, house, and type specimens collected by Anders Regnell - a. portrait in graphite of Anders Regnell, unknown authorship, with his personal rubric, item from Regnellian herbarium collection; b. Regnell's house and street where he lived in Caldas, MG, Brazil. Photo by S. Henschen (scanned from Dahlgren 1962). Type specimens of plants collected in the region of Caldas - c. Abutilon peltatum K. Schum.; d. Vochysia magnifica Warm.; e. Ipomoea malvaviscoides Meisn. Plant specimens from the Regnellian herbarium collection and were scanned respectively by Johannes Lundberg (S), Daniel Andersson (S), and Gunilla Lehman (S). 
Regnell was doubtless one of the most important collectors of his time and his legacy goes beyond his collections and fortune. Much of the plants collected by him and his sponsored contributors formed the basis for the elaboration of the "Flora brasiliensis" of Carl F.P. von Martius, which remains the most remarkable publication embodying Brazilian flora (Figs. 3; 4). Regnell's importance to botany is celebrated in three genera named in his honor (Fig. 4): Regnellia (Orchidaceae), Neoregnellia (Sterculiaceae) and the monotypic Regnellidium (Marsileaceae); and in more than 150 species designated under epithets derived from his name such as regnellii, regnelliana or regnellianum.

Per Karl Hjalmar Dusén - The Swede who discovered Paraná

The second largest collection of Brazilian plants in the Regnellian herbarium was gathered by Per Karl Hjalmar Dusén (Fig. 5a). He collected mainly in the state of Paraná, but also in Santa Catarina, São Paulo, and Rio de Janeiro, during the beginning of the twentieth century. His collection in $\mathrm{S}$ encompasses more than 13,000 specimens and almost 900 types. The Regnellian herbarium also keeps Dusén's field books, personal notes and wares from his time (Fig. 6a). The best represented families in his collections are Asteraceae (ca. 3,200 specimens), Orchidaceae (ca. 2,100), and Poaceae, Apocynaceae, Solanaceae and Piperaceae with ca. 500 specimens each.

The botanist, explorer, and engineer Dusén was born in Vimmerby, Sweden, in 1855 . He became a civil engineer at age of 26 but only dedicated himself to that profession until 1880 . Influenced by his father, Dusén returned to the University to study Natural Sciences. Once graduated, he was hired by the Swedish Museum of Natural History in Stockholm as assistant curator. During that period he began his career as botanical explorer (Knutson 2002), taking his first expedition to Tropical Africa, (1890-1892), in which he acted as cartographer, geologist, and botanist. That trip made him known as the "discoverer of Real bryology of East Africa", as he collected and described 300 new species of mosses from Cameroon, Equatorial Guinea and Liberia. In 1895 he joined an expedition to Patagonia and Tierra del Fuego, led by the Swedish mineralogist and geologist, Otto Nordenskjöld (Nordenskjöld 1898). This expedition resulted in several publications of his studies of bryophytes and phanerogams from the so-called "Magellanica" land. He also described the physiognomy of Patagonia vegetation in "Reports of Princeton

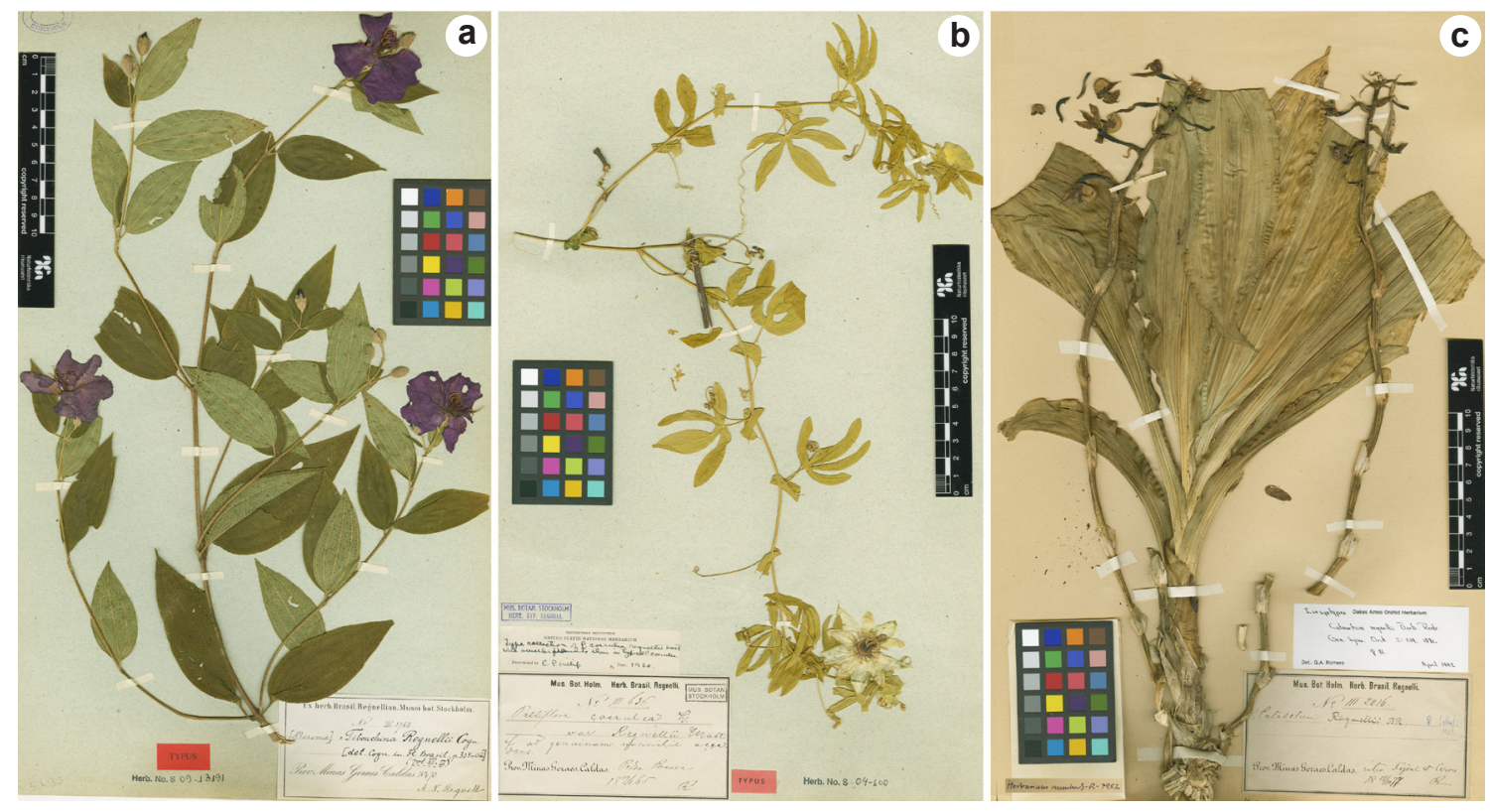

Figure 4 - Type specimens of plants named in honor of Anders Regnell - a. Tibouchina regnellii Cogn.; b. Passiflora caerulea var. regnellii Mast.; c. Catasetum regnellii Barb. Rodr. Specimens from the Regnellian herbarium collection scanned by Dennis Strid (S) and Frida Eggens (S). 
University Expeditions to Patagonia, 1896-1899". This report earned Dusén the Honorary Doctorate in Botany from the University of Princeton (Hatcher \& Scott 1914).

His expeditions to Brazil began in 1901 when he was appointed to a position of
"Assistant botanist" at the National Museum of Rio de Janeiro. He transferred to Paraná state in November 1903, and devoted himself extensively to the study of that flora, receiving funds from the local government during the periods 1903-1904, 1908-1912, and 1913-1916.
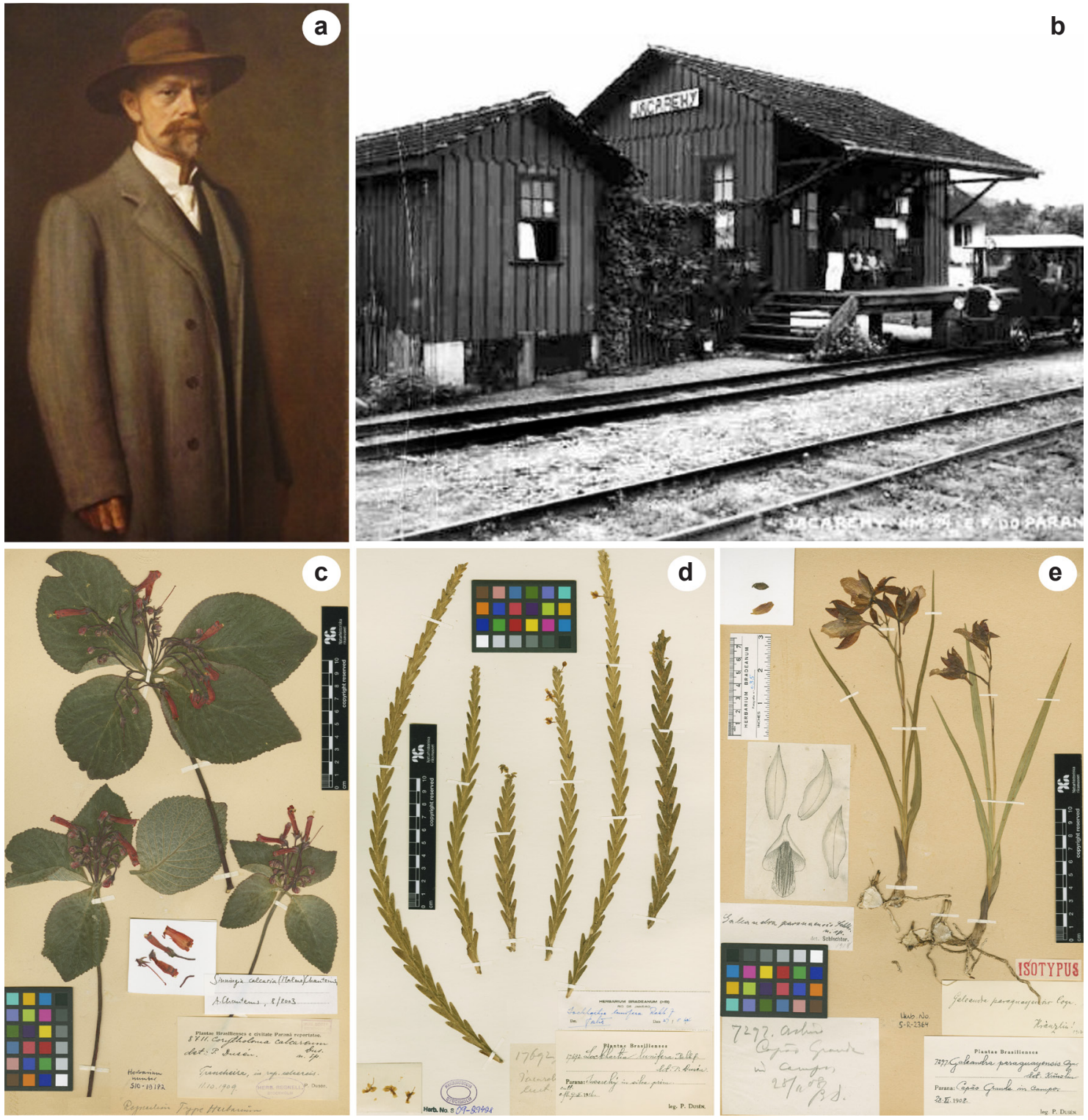

Figure 5-Portrait, old train station in Paraná, where Per Dusén used to collect, and some type specimens collected by him in the region -a. portrait of Per Dusén painted by Norwegian artist Alfredo Andersen (photo is a courtesy of Alfredo Andersen Museum collection Curitiba, and the use authorized by Debra Fischer Bassler from the same institution); b. Jacarehy station, often cited on the labels of Dusén's collection, now called Saquarema station, municipality of Morretes, PR, Brazil (photo: Ricardo Pinto da Rocha, downloaded from estacoesferroviarias.com.br and use authorized by Ralph M. Giesbrecht owner of website); c-e. plants collected by Dusén along the old train stations of Paraná - c. type of Corytholoma calcarium Dusén ex Malme, collected in Trancheira; d. Lockhartia lunifera (Lindl.) Rchb.f., collected in Jacarehy; e. Galeandra paraguayensis Cogn., collected in Capão Grande. Specimens from the Regnellian herbarium collection imaged by Karin dos Santos (S) and Johannes Lundberg (S). 
Besides the lush flora of Paraná state and the large number of plants to be described in the region, other factors contributed to Dusén remaining in the state for so many years, such as his friendship with Carlos J.F. Westerman, director of railways of the state of Paraná. To support Dusén, Westerman gave him a train car transformed into dormitory, which also served as laboratory for his collections and research (Hoehne 1930). Dusén traveled this way throughout the region. When he
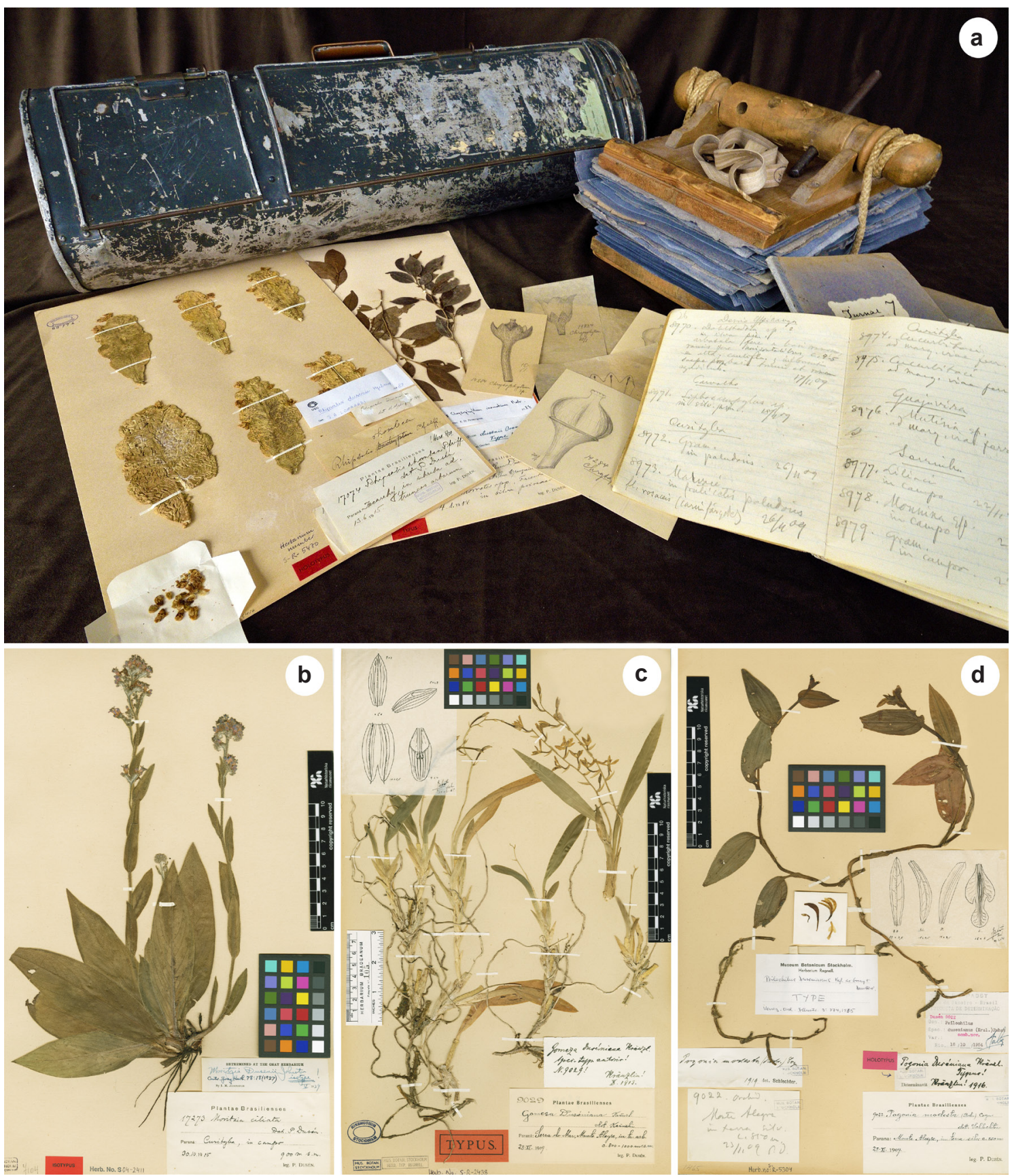

Figure 6 - Plant specimens collected by Dusén and some utensils used by botanists in the early twentieth century - a. Dusén's specimens, his field books and illustrations, a plant press and collection container from his period [photo by Johannes Lundberg (S)]. b-d. type specimens of plants named in honor of Dusén - b. Moritzia dusenii I. M. Johnst.; c. Gomesa duseniana Kraenzl.; d. Psilochilus dusenianus Kraenzl. ex Garay \& Dunst. Items and specimens from Regnellian herbarium collection imaged by Heather Wood (S), Karin dos Santos (S), and Johannes Lundberg (S). 
was done exploring a particular area, his special wagon was hitched to a locomotive and taken to yet another place to be examined. It remained there for a further period, moving along once again when he finished his research. Therefore, the vast majority of plants collected by Dusén can possibly be found by following the railway routes ranging from São Paulo, Paraná, and the borders of the Santa Catarina state (Hoehne 1930). Many of the locations of his collection labels refer to old train stations of these lines, for example Jacarehy, Jaguarahyva, Desvio Ribas, Saquarema, etc. (Fig. 5a-d).

Among the nearly 250 species described by Dusén, we highlight those belonging to Astearaceae, Poaceae, Solanaceae, Lamiaceae, and Euphorbiaceae. Most of these species (170) have their types housed in the Regnellian herbarium. Accurate illustrations are frequently found attached to his specimens giving us the picture of a dedicated researcher (Figs. 5e; 6a,c-d).

Dusén died in Tranås, Sweden, in 1926. During his life he gathered approximately 70,000 specimens of vascular plants and more than a thousand bryophytes. The majority of his collections are stored in the Museum of Natural History in Stockholm but some can also be found in Brazilian herbaria of Rio de Janeiro and Curitiba. Unfortunately, most of the material left by Dusén in Brazil was destroyed, as well as most of his material deposited in New York, lost in a alleged fire. This makes his collections at the Regnellian herbarium even more significant. The importance of Dusén for botany is also reflected in the large number of materials collected by him and designated as type by other researchers. Most of these were collected in Brazil (591 types). His legacy is recognized by the herbarium of Curitiba, which was named in his honor as the Herbarium Per Karl Dusén (PKDC), as well as the eponymous genera Dusenia O. Hoffm. and Duseniella K. Schum., and another 160 species celebrating Dusén with the epithets dusenii, duseniana, dusenianum, and per-dusenii etc. (Fig. 6b-d).

\section{Oskar Andersson Gustaf Malme - The first Regnellian Explorer \\ Oskar Andersson Gustaf Malme (Fig. 7a)} was born at the village of Stora Malm in Sweden on October 24, 1864. He earned his Bachelor degree in Botany at University of Uppsala, in 1888 and became Doctor of Philosophy in 1892
(Arwidsson 1937). During his career, he worked at the Regnellian herbarium in Stockholm in different occasions. The first position he occupied was as Regnellian Amanuensis (1895-1901), a curate position supported by the Regnellian Fund (Lindman 1916). Between 1904 and 1905 he worked as Curator of Botany, and after his retirement, Malme again became Regnellian Amanuensis until 5th Mars 1937, when he died at the age of sixty-two (Arwidsson 1937). However, for most of his life, he worked as a lecturer in biology, zoology and chemistry.

Gustaf Malme, together with Carl Lindman, was the first Swedish botanist to receive financial support from the Regnellian Fund. According to the statute of the fund, the contemplated should collect plants in "Brazil or other inter-tropical country" during a period of two years. Thus, during the years 1892-94, the two botanists undertook the "first expedition Regnelliana" (Expeditio I.moe Regnellianae) to Brazil (Baptista 1996), visiting the states of Mato Grosso and Rio Grande do Sul and later extending to the central areas of Paraguay. Despite rumors of disagreements between the two botanists, the outcome of the trip was substantial; over 5,000 specimens were gathered (Fig. 7b-c).

Between 1901 and 1903, Malme was once again granted with Regnellian funds to go to Brazil, undertaking the "second expedition Regnelliana” (Plantce Itineris Regnelliani II.di). Traveling alone this time, he revisited Rio Grande do Sul and Mato Grosso, passing briefly through Paraguay and Argentina (Aconcagua, Mendoza).

The original trip plan was to start in Rio Grande do Sul, in order to complete some preliminary research. After that, he would leave to Aconcagua in the Argentine Andes and continue the trip throughout Mato Grosso. However, the trip to Aconcagua, located on the border between Argentina and Chile, would be risky at that moment due to conflicts over territorial disputes around the borders between the two countries. The region of Mato Grosso also seemed somewhat unfavorable for expeditions, because there was a threat of civil war. Thus, his stay in Rio Grande do Sul was prolonged to almost six months (Fig. 7d). That allowed him to explore the localities of Cachoeira and Santa Cruz. Also in an unforecasted manner, his passage through Paraguay had to be extended, about which he wrote: "I had no reason to regret the short stay in Paraguay. By Professor Dr. J. D. Anisits, who I already knew from my 
previous journey, I was cordially received, and on behalf of the Riksmuseum I received a considerable collection of phanerogams from the very little examined north-west part of Paraguay" (Malme 1904).
When he arrived at Cuiabá, Mato Grosso, Malme observed that the civil war had left its tragic imprint. He reports that it was impossible to get a working-animal to carry his luggage, since most had been killed or stolen during the war. $\mathrm{He}$

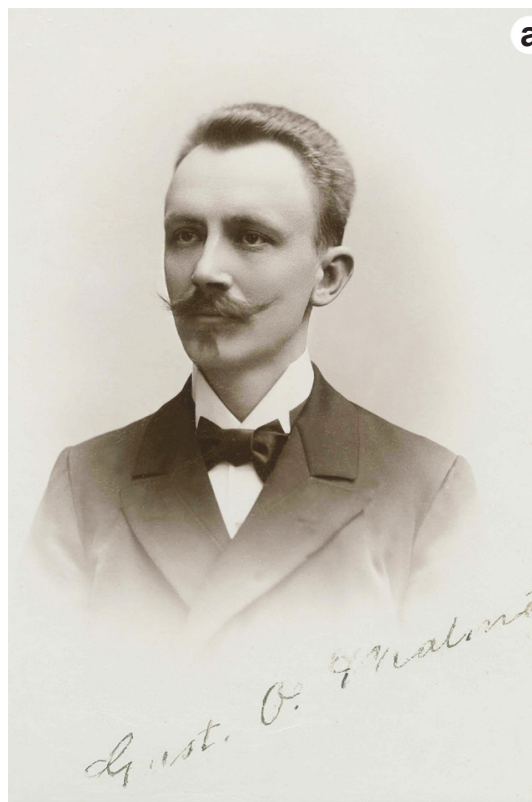

a
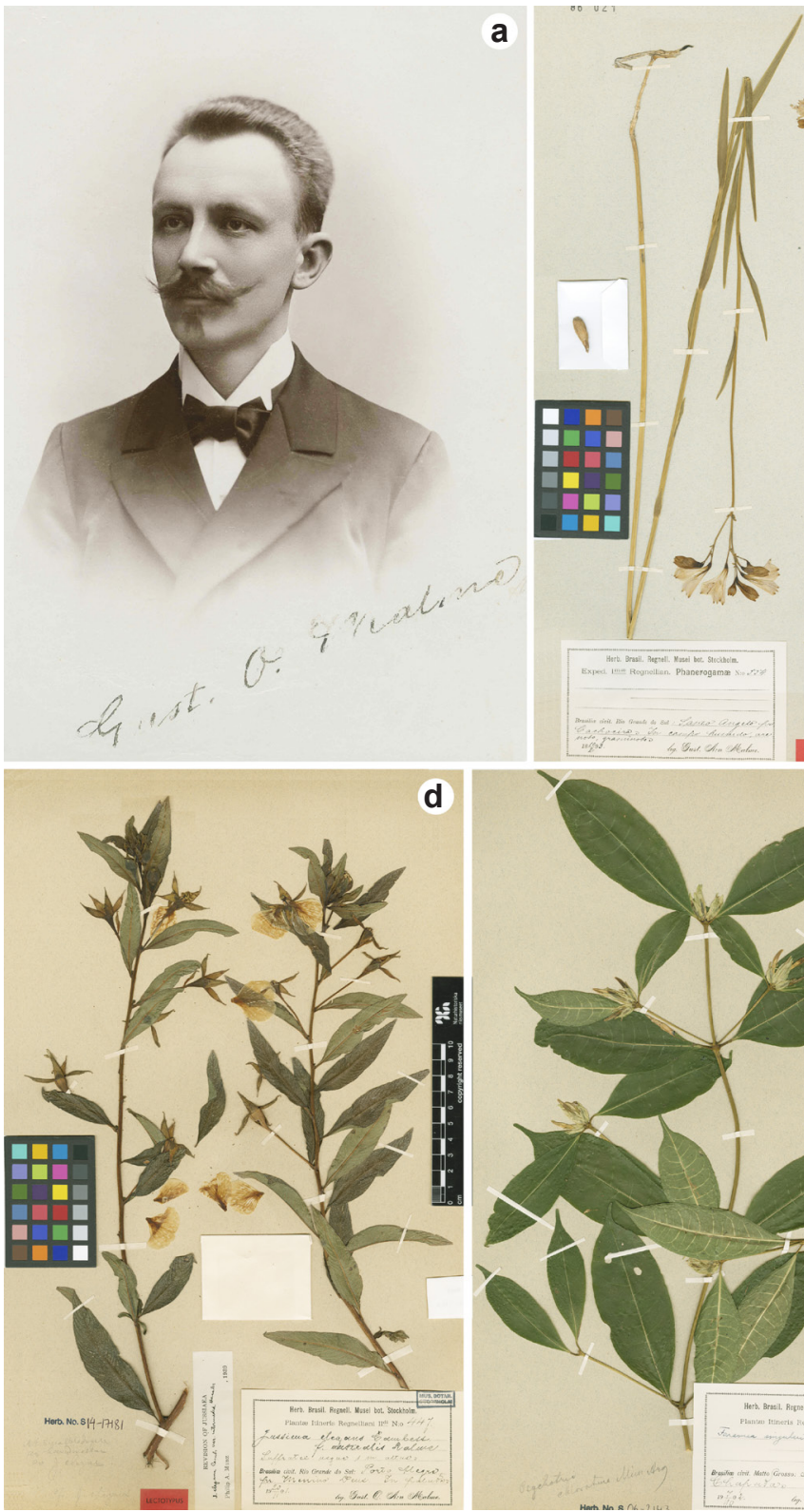

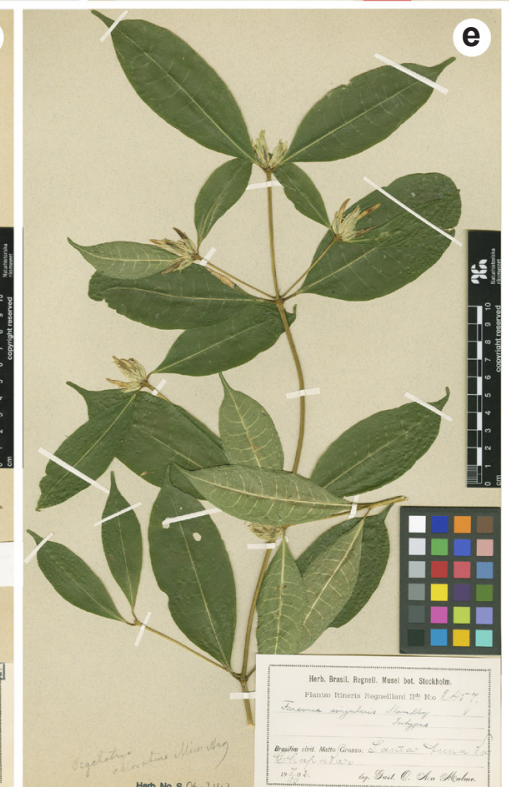

b
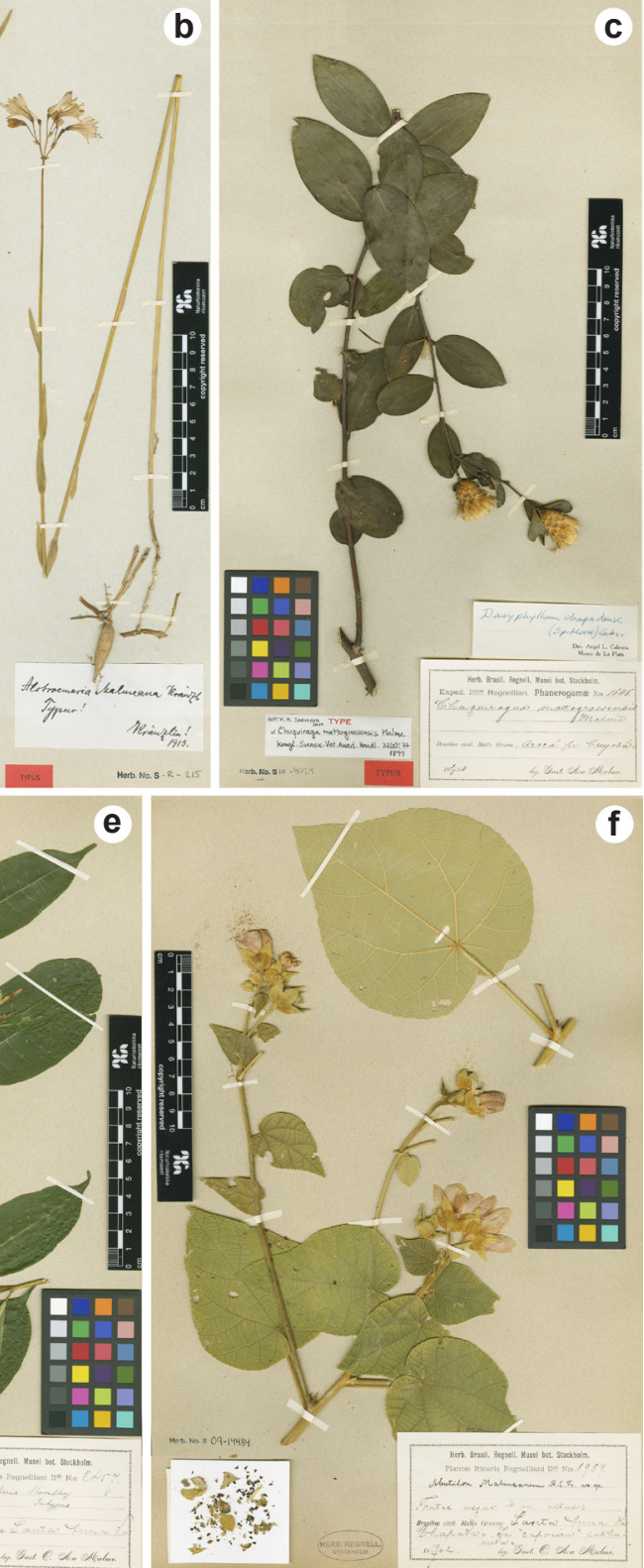

Figure 7 - Portrait and type specimens collected by Gustaf Malme in his expeditions to Brazil in early twentieth century - a. portrait of Gustaf Malme with personal rubric (item from Regnellian herbarium collection). Type specimens of plants collected during the "first expedition Regnelliana" to Brazil - b. Alstroemeria malmeana Kraenzl., collected in Rio Grande do Sul; c. Chuquiraga mattogrossensis Malme, collected in Mato Grosso. Type specimens collected during the "second expedition Regnelliana" - d. Jussiaea elegans fo. australis Malme from Rio Grande do Sul; e. Faramea singularis Standl. and f. Abutilon malmeanum R. E. Fr. collected in Mato Grosso. Specimens from Regnellian herbarium collection, imaged by Johannes Lundberg (S), Gunilla Dahlerus Lehman (S), Karin dos Santos (S), and Dennis Strid (S). 
managed, despite that, to set off for Santa Anna da Chapada, a region currently known as Chapada dos Guimarães. In Santa Anna da Chapada, there was no available shelter other than a room at the village church, since "...most houses were in decay and hardly livable or at least extremely unsuitable for someone who incessantly needs to protect his collections from the damp."

Malme describes the outskirts of Santa Anna Chapada as "an inexhaustible field for a botanist". His collections grew so rapidly there, that only a month after his arrival, he had to return to Cuiabá to sort and pack specimens (Fig. 7e-f). After over a month in Santa Anna, Malme traveled to Buenos Aires to conduct the planned tour to Aconcagua at c. 3,000 meters above sea level. The vegetation there was very poor though, with only fifty or so phanerogams known from the area. Malme enriched records for the region adding 130 specimens of plants. Altogether, Malme collected ca. 2,600 numbers during his second South American expedition.

The material gathered by Malme amounts to almost 6,000 specimens of lichens, 1,000 fungi 5,000 ferns and an estimated 12,000 angiosperms. Most of his collections are kept in the Museum of Natural History in Stockholm, with some duplicates in Uppsala, Lund, and Rio de Janeiro. Thanks to his journeys to South America and his work in the Regnellian herbarium, Malme became an eminent expert on the flora of South America, publishing more than one hundred articles at the Kungliga Svenska Vetenskapsakademiens Handlingar, mainly specialized in Asclepiadaceae, Xyridaceae, and Asteraceae. Malme's contribution to the knowledge of the flora of Rio Grande do Sul was highlighted by Baldwin Rambo, who pointed out that the number of species with occurrence in the state tripled after the passage of Gustaf Malme (Baptista 1996). He was also one of the most prominent researchers of lichens at that time, publishing 40 fascicles of Lichenes suecici exsiccati (1897-1926) and 13 fascicles of Lichenes Austroamericani ex Herbario Regnelliano (1924-1936).

Five genera of plants, lichens and fungi were named after Gustaf Malme, lichens Malmella and Malmia, and the fungal genus Malmeomyces. Among the angiosperms, two genera were named in reference to Malme, Malmeanthus (Asteraceae) and Malmea (Annonaceae), described by Robert Elias Fries in 1905. Another 61 species were named in his honor with epithets malmeana, malmeanum, and malmei (Fig. 7b,e). The type for Malmea obovata, on which Fries based the designation of his new genus, is also stored in the Regnellian herbarium.

Walter Adolpho Ducke - a giant in the Amazon jungle

Adolpho Ducke (1876-1959) was an Italian entomologist, botanist, and ethnographer who became highly respected for his work in the Amazon. Ducke (Fig. 8a) started his activities in the Goeldi Museum in June 1899 after the invitation of Dr. Emilio Goeldi, during one of his trips to Europe. Initially he worked as an entomologist in the Zoology Section, but under the influence of Jacques Huber, an eminent botanist of that institution, his focus was gradually turning to botany (Archer 1962). At that time, little was known of the flora of Amazonian forest. The difficulties of collection, irregular flowering, fertile samples difficult to spot due to the height of the trees, problems of access and establishment at remote regions, were some of the obstacles to overcome (Archer 1962). Ducke managed all these problems, creating the current techniques for plant collection and monitoring tree phenology. He located the trees in bloom by observing the forest floor in search of fallen flowers or listening to the sounds of animals that gather nectar or fruits. He also instructed and trained local people in techniques for climbing trees and collecting botanical samples. When additional botanical material was necessary, he used to mark and make repeated trips to visit particular trees. Through repeated visits to those remote locations, he became an expert on the region and on local and regional flora (Egler 1963). His persistence, patience, and meticulousness established him as one of the most respected investigators of the Amazon flora until the present day.

His research, besides his transit between entomology and botany, also extended beyond the limits of the Amazon. Ducke studied deeply the tree flora of the states of Pernambuco and Ceará, scarcely known at that time, assisting the reorganization of the herbaria of those states.

Ducke became a legendary and respected figure in the Amazon basin, and not only for his great capacity for work. His unusual stature for the region (1.95 $\mathrm{m}$ tall), his constant trips to remote places, always accompanied by vast baggage and performing weird jobs, were viewed with strangeness by the locals, and created a mystique 
around him. His stature was the target of anecdotes and mockery, which he was amused to propagate. Many natives in the region, according to Egler (1963), believed that Ducke had sold his skeleton for a Museum to be studied after his death.
Already in the 1950's, Ducke was concerned about the future of the Amazonian forest. This led him to make a suggestion to the National Institute of Amazonian Research (INPA) to establish a nature reserve. Unfortunately, Ducke did not
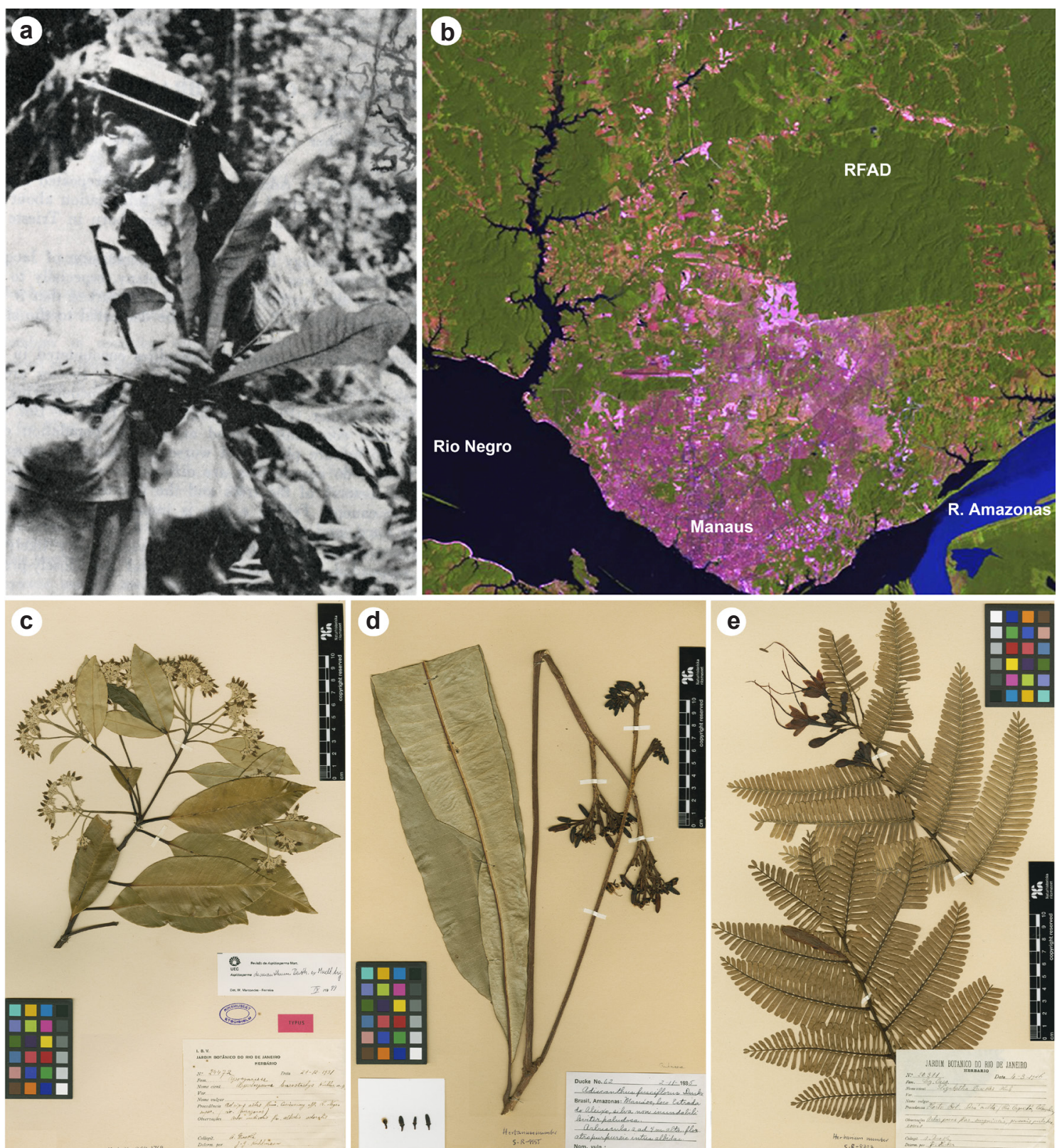

e
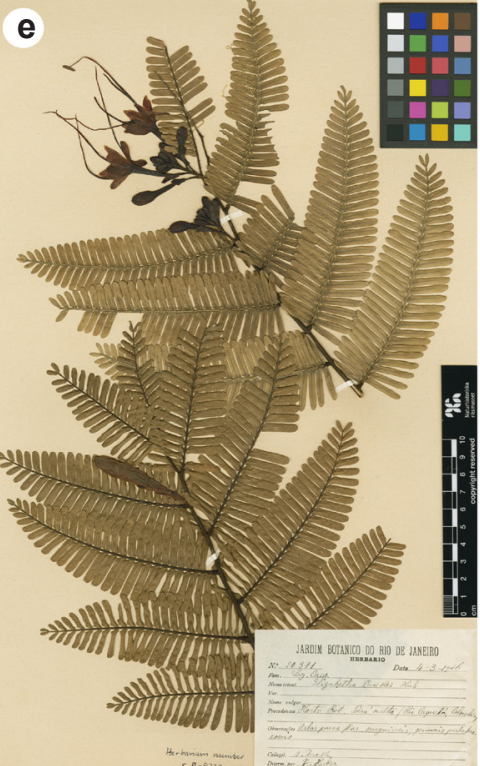

Figure 8 - Picture, region of collection and plant specimens collected by Adolpho Ducke - a. picture of Adolpho Ducke scanned and edited from Archer (1962); b. satellite image showing the location of the Adopho Ducke Forest Reserve (RFAD) at the outskirts of the city of Manaus, AM, Brazil [image use and source provided by National Institute of Amazonian Research-INPA/MCT, authorized by Flavia Pezzini (INPA)]. Type specimens of plants collected by Adolpho Ducke in Amazonian forest - c. Aspidosperma leucostachys Kuhlm. ex Markgr.; d. Adiscanthus fusciflorus Ducke; e. Elizabetha duckei Huber. Specimens from Regnellian herbarium collection imaged by Karin dos Santos (S). 
live to witness the realization of this desire, but in 1963, the area indicated by Ducke was established as the Reserva Florestal Adolpho Ducke, created and named in his honor (Fig. 8b). The botanical garden east of the city of Manaus and the phytochemical research laboratory of the Emilio Goeldi Museum in Belém were also named after him.

During his prolific botanical career, Ducke published about 200 articles and monographs, most of them on the Leguminosae. According to the "International Plant Names Index" (IPNI), Ducke described over 1,300 taxa, fifty of them being new genera, a remarkable achievement, since the total number of tree species in Amazon is estimated to ca. 12,500 (Hubbell 2008). The Regnellian herbarium in Stockholm houses about 650 type specimens collected by Adolpho Ducke, with 550 of these being taxa described by him (Fig. 8c-e). The genera Duckeodendron Kuhlm., Duckesia Cuatrec., Duckeella Port \& Brade, Duckea Maguire, among others reveals Ducke's influence on botanical taxonomy. He is also honored in more than 150 species designated under epithets derived from his name (Fig. 8d).

Auguste François Marie Glaziou - a French of imperial gardens

Auguste François Marie Glaziou (18281906) was a French landscape designer who born in Lannion (Fig. 9b), France. In 1858, Glaziou departed to Brazil after an invitation of the Emperor of Brazil, Dom Pedro II, who appointed him as General Director of Public Gardens for the city of Rio de Janeiro. Later, he widened his responsibilities by being appointed as General Director of Public Gardens and Forests for the state of Rio de Janeiro, a position he performed until 1895, when he retired and returned to Europe (Leandri 1963). Glaziou was responsible for landscape design at several sites, e.g., the gardens at Quinta da Boa Vista and the residence of the Brazilian royalty.

During his tenure in Brazil he was also active as a plant collector and botanist and established good contact with some of the greatest of his time, such as Martius, Regnell, Cogniaux, among others. His botanical explorations began in the state of Rio de Janeiro, as far as Serra dos Orgãos and Serra de Itatiaia, later extending his excursions to Minas Gerais and São Paulo (Fig. 9a,c). Three times he made expeditions to the province of Espírito Santo, and the last two years in Brazil were devoted to a large and very successful exploration to the province of Goyaz (Cogniaux 1906) (Fig. 9d-e).

In 1897, after almost 40 years in Brazil, Glaziou returned to France and settled in Bordeaux, where he dedicated himself to organize and study his collections. The first volume of his "Plantae Brasiliae Centralis a Glaziou lectae", was published in the Bulletin de la Société de la France, in 1905. The second volume was released after Glaziou's death from pulmonary infection, in 1906.

Some authors have reported a few incongruences of his collections' dates and localities (Sleumer 1954; Smith 1966; Wurdack 1963). For this reason Wurdack (1963) recommends caution about Glaziou data when his collection locality is the only evidence of disjunct species distribution or when a species is known only from a Glaziou collection. Nevertheless, Glaziou's contribution to the knowledge of Brazilian flora is undeniable. During his life, he collected circa 24,000 numbers, with material enough to produce the impressive number of 240,000 samples (Leandri 1963). In total, the number of species inventoried by him sum up to 12,000 species, being ca. 700 new species. Several of these collections were also examined for Martius' 'Flora Brasiliensis' and designated as type material in that publication.

His collections were distributed to Berlin, Paris, Brussels, Kew, St. Petersburg, Copenhagen, Stockholm, Geneva, Montpellier, and Rio de Janeiro. The Regnellian Herbarium houses 542 types, approximately 3,000 specimens from Goiás' expedition, and another 5,000 from other Brazilian regions. Many Botanical Gardens in Europe had also received quantities of living plants and seeds from him - the famous collection of Bromeliads at the Botanical Garden of Liege, for example, includes a large number of specimens sent by Glaziou from Brazil (Cogniaux 1906).

Glaziou's contribution is recognized in more than 400 species named under epithets derived from his name, such as glaziovii, glazioviana, and glaziovianum (Fig. 9c). The botanist is also celebrated in several genera: Glaziova Bureau (Bignoniaceae), Glaziostelma E. Fourn. (Apocynaceae), Glaziophyton Franch. (Poaceae), Bisglaziovia Cogn. (Melatomaceae), Glaziophytum Cogn. (Melastomataceae), Neoglaziovia Metz (Bromeliaceae), and Glaziocharis Taub. (Burmanniaceae). 

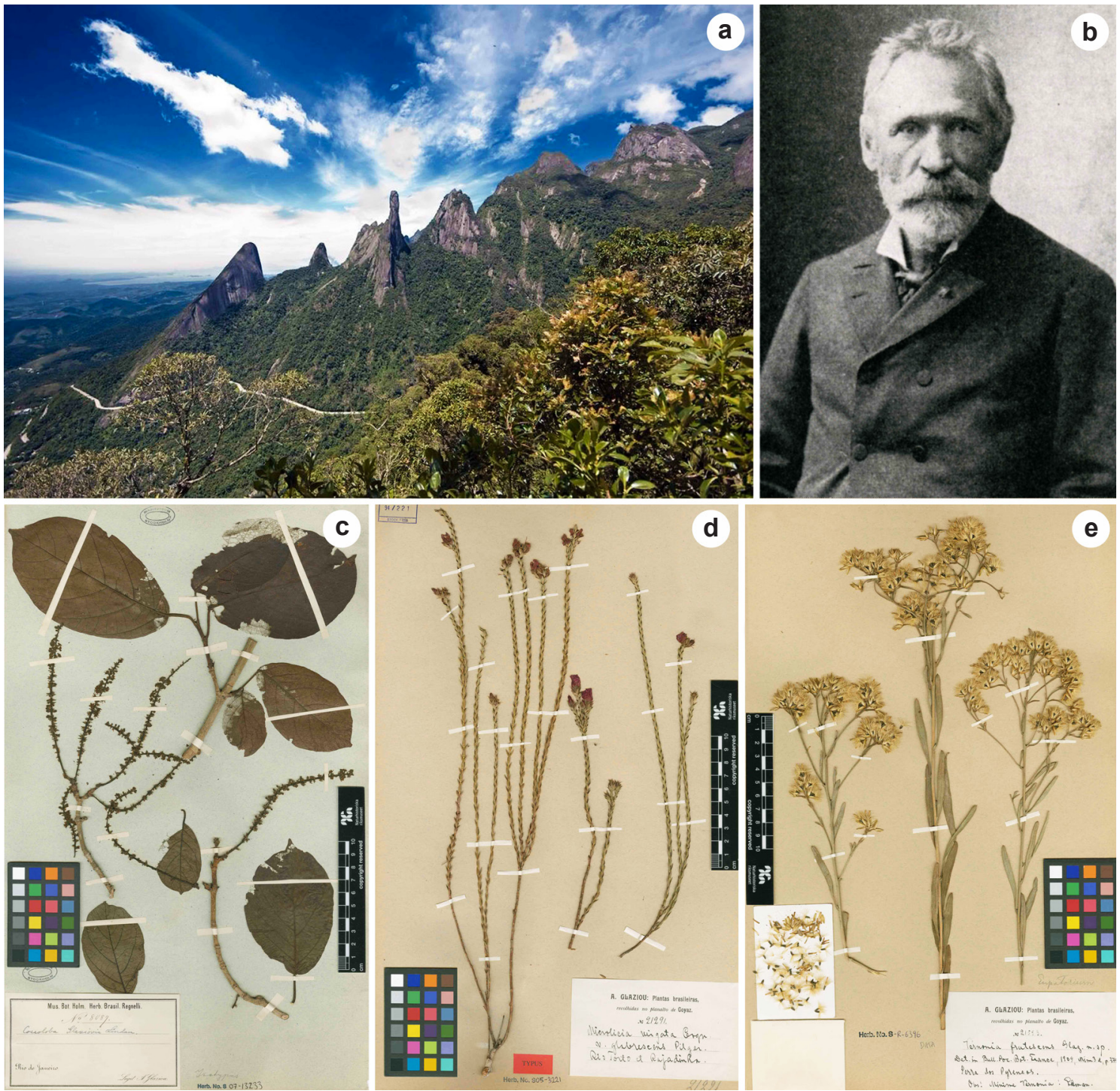

Figure 9 - Portrait, region of collection and plant specimens collected by Auguste Glaziou - a. Serra dos Órgãos National Park, RJ, Brazil where Glaziou collected extensively during his stay in Brazil; b. portrait of Auguste Glaziou scanned from Leandri(1963); c. type of Coccoloba glaziovii Lindau E. Fourn. collected in Rio de Janeiro. Type specimens collected during his excursion to the Goiás state - d. Microlicia virgata var. glabrescens Pilg.; e. Vernonia frutescens Glaz. National Park photo authorship and authorization by Milton Tavares. Specimens from Regnellian herbarium collection imaged by Karin dos Santos (S) and Heather Wood (S).

\section{Acknowledgements}

To Mia Ehn from Swedish Museum of Natural History, and Prof. Dr. Paulo Labiak from Federal University of Paraná, for references and help with the manuscript. To Ralph M. Giesbrecht from estacoesferroviarias.com.br, for allowing the use of the old station Jacarehy's photograph. To Debra Fischer Bassler from Alfredo Andersen Museum, Curitiba, by allowing the use of the portrait of Per Dusén. To Flavia Pezzini to the National Institute of Amazonian Research - INPA/ MCT, for allowing the use of the satellite image of the Ducke Reserve. To Milton Tavares, for the photograph of Serra dos Orgãos, Rio de Janeiro. Heather Wood, for reviewing the English. And the two referees, for comments and suggestions that helped improving the first version of the manuscript. 


\section{References}

Archer, W.A. 1962. Adolpho Ducke, botanist of the Brazilian Amazon (1876-1959). Taxon 11: 233-242.

Arwidsson, T. 1937. G.O.A. Malme 24.X.1864-5. III.1937. Revista sudamericana de Botanica 5: 44-46.

Baptista, L.R.M. 1996. Gustav Malme e a flora do Rio Grande do Sul. Ciencia \& Ambiente 13: 99-105.

Cogniaux, A. 1906. Notice biographique sur Auguste Glaziou. Bulletin de la Socièté Royale de Botanique de Belgique 43: 364-369.

Concha Quezada, H. 2012. Anders Fredrik Regnell (1807-1884). Médico, botanista y mecenas en Suecia y Brasil. RIL editores, Santiago de Chile. 226p.

Dahlgren, K.V.O. 1962. Anders Fredrik Regnell och hans svenska gäster i Brasilien, särskilt Gustaf A. Lindberg och Salomon E. Henschen. Svensk Botanisk Tidskrift 56: 391-470.

Egler, W.A. 1963. Adolpho Ducke - traços biográficos, viagens e trabalhos. Boletim do Museu Emílio Goeldi. Nova série, Botânica 18: 1-129.

Hatcher, J.B. \& Scott, W.B. 1914. Reports of Princeton University expeditions to Patagonia (1896-1899). The University. Schweizerbart, Stuttgart, Princeton. $224 \mathrm{p}$.

Hoehne, F.C. 1930. Araucarilândia: observações gerais e contribuições ao estudo da flora e phytophysionomia do Brasil. Secretaria da agricultura, industria e comércio do estado de São Paulo, São Paulo. 322p.

Hubbel, S.P.; He, F.; Condit, R.; Borda-de-Água, L.; Kellner, J. \& Ter Steege, H. 2008. How many tree species are there in the Amazon and how many of them will go extinct? Proceedings of the National Academy of Sciences. Vol. 105, Suppl. 1. Available at <http://www.pnas.org_cgi_ doi_10.1073_pnas.0801915105>. Access on 31 October 2016.

Knutson, K. 2002. Swedish Ventures in Cameroon, 18331923: trade and travel, people and politics. Berghahn Books, Oxford. 304p.

Leandri, J. 1963. Un botaniste français pionnier de la floristique brésilienne. Adansonia 3: 5-18.

Lindberg, B.S. 2011. Anders Fredrik Regnell (Elektronisk resurs: läkare, botanist och donator). Skrifter rörande Uppsala universitet. C, Organisation och historia. Acta Universitatis Upsaliensis, Uppsala. 244p.

Lindman, C.A.M. 1916. Botaniska afdelning 93-129. In: Lönnberg, E. (ed.). Naturhistoriska Riksmuseets historia dess uppkomst och utveckling. Almqvisy \& Wiksells, Stockholm. 290p.

Lughadha, E.N. \& Miller, C. 2009. Accelerating global access to plant diversity information. Trends in Plant Science 14: 622-628.

Malme, G.O. 1904. Reseberättelse, Vetenskapsakademiens Årsbok. Naturhistoriska Riksmuseets. Almqvisy \& Wiksells, Stockholm. 57p.

Nordenskjöld, O. 1898. Från Eldslandet: skildringar från den Svenska expeditionen till Magellansländerna, 1895-97. P.A. Norstedt \& Söners Förlag, Stockholm. $254 \mathrm{p}$.

Sleumer, H. 1954. Proteaceae americanae. Botanische Jahrbücher für Systematik, Pflanzengeschichte und Pflanzengeographie 76: 139-211.

Smith, L.B. 1966. The great bromeliad hoax. Bromeliad Society Bulletin 16: 4-5.

Wurdack, J.J. 1970. Erroneous data in Glaziou collections of Melastomataceae. Taxon 19: 911-913. 